WIENER SLAVISTISCHES JAHRBUCH, Band 54/2008, 91-104

(C) 2008 by Österreichische Akademie der Wissenschaften, Wien

STELA MANOVA

\title{
Closing Suffixes and the Structure of the Slavic Word: Movierung ${ }^{1}$
}

\section{INTRODUCTION}

Affix ordering in terms of restrictions on affix combinations is a central issue in morphological theory. However, the topic is not very popular in Slavic linguistics and it seems appropriate therefore to provide a more comprehensive introduction than is customary.

One expects that all affixes in a given language should be able to combine with one another. There are, however, severe restrictions on possible affix combinations. Unfortunately, a precise and universal mechanism governing affix order has not been identified thus far, despite a number of (typological, phonological, syntactic, semantic, psycholinguistic, and morphological) attempts.

Research on typologically unrelated languages reveals some general tendencies, e.g. inflectional suffixes follow derivational affixes (Greenberg 1968); crosslinguistically, aspect suffixes precede tense suffixes in the verb form (Bybee 1985), etc. Yet the most influential proposal in regard to affix order is perhaps that of the theory of Level (Stratal) Ordering (incorporated into Lexical Phonology and Morphology). According to the stratal ordering (Siegel 1974, Kiparsky 1982, Mohanan 1986, Giegerich 1999, among others), affixes can be divided into various lexical levels (strata) that, phonologically and morphologically, interact in complex ways. The stratal approach distributes English suffixes and prefixes into two levels: class I and class II. This distribution is explained by observations such as: class I affixes

1 The Austrian Science Fund (FWF), through Elise Richter Fellowship grant V64-G03, supported this research. Their support is gratefully acknowledged. - Due to space limitations, the German term Movierung is preferred to the English "derivation of females from males'. - Abbreviations: B. - Bosnian; Bg. - Bulgarian; Cr. - Croatian; DIM - diminutive; E. - English; FEM - feminine; G. - German; GEN - genitive; MASC - masculine; $\mathrm{N}$ - noun, NOM - nominative; P. - Polish; PL - plural; R. - Russian; RNC - Russian National Corpus; S. - Serbian, SG - singular; V - verb. 
frequently attach to bound roots and tend to be phonologically less transparent than class II affixes; class I affixes cause stress shifts, resyllabification, and other morphonological alternations, whereas class II affixes do not; class I affixes are less productive and less semantically transparent than class II affixes; class I affixes do not occur outside class II affixes. According to this interpretation, affixes always combine so as to attach to affixes of the same or a lower stratum, thus ruling out other possible combinations.

On the syntactic side, it is assumed that morphology 'mirrors' syntax and that this principle determines the order of morphemes (Baker 1985). Semantic approaches argue that semantic relevance (Bybee 1985) and semantic scope (Rice 2000) govern affix order. Psycholinguistic approaches assume that psycholinguistic properties such as 'easily parsable' (cf. class II affixes of Lexical morphology) and 'difficult to parse' (cf. class I affixes above) are responsible for affix order (Hay 2003). Finally, approaches that I refer to as 'morphological' look to restrictions encoded either in the base (of an affixation change), in the affix itself, or in both (cf. Plag 1996).

Recent research on affix ordering involves the notion of closing suffixes (Nida 1949; Szymanek 2000; Aronoff - Fuhrhop 2002). Closing suffixes 'close' the word to additional suffixation. Clearly, in languages with sets of derivational and inflectional suffixes, derivational and inflectional closing suffixes should be acknowledged (cf. Aronoff - Fuhrhop 2002). A well-known example of a closing derivational suffix from the literature is the German Movierung suffix -in (cf. Aronoff Fuhrhop 2002). Consider the following examples:

(1a) Lehrer 'teacher' $\rightarrow$ Lehrerin 'female teacher'

(1b) Lehrerin $\rightarrow$ *Lehrerin-chen 'little female teacher'

versus

(1c) Lehrer $\rightarrow$ Lehrer-chen 'little teacher'

According to Aronoff \& Fuhrhop (2002), if Lehrerin is used as a first constituent of a compound or before the suffixoids -shaft and -tum, a linking element 'reopens' it, thus Lehrerinn-en-zimmer 'a room for female teachers', Lehrerinn-en-schaft and Lehrerinn-en-tum.

Note, however, that there is a significant distinction between German and Slavic Movierung in regard to its formal expression and Movierung in Slavic can be formally realized either by an overt suffix that seems to be derivational (the default case parallel to the German Movierung by -in, e.g. Bg. učitel 'teacher' $\rightarrow$ FEM $u c$ citel-k-a) or by addition of inflection only, i.e. without an overt Movierung suffix (e.g. Cr. bratučed 'cousin' $\rightarrow$ FEM bratučed-a; susjed 'neighbor' $\rightarrow$ FEM susjed-a, suprug 'husband' $\rightarrow$ suprug- $a$ 'wife', Bg. săprug 'husband' $\rightarrow$ săprug- $a$ 'wife', R. suprug 'husband' $\rightarrow$ suprug- $a$ 'wife', etc.). Significantly, whereas over $90 \%$ of German Movierung formations are derived with the suffix -in (Wellmann 1975: 109), each Slavic language exhibits a set of relatively equally well-established Movierung suffixes. Thus it is proposed herein that analysis of instances of Movierung from 
Slavic (primarily from Bulgarian and Russian) may establish: 1) whether Movierung is closing due to the (modification nature of the) semantic change it causes and if so, 2) whether the closing character of Movierung is exceptionless. In this way, the mechanism of closing suffixation may be determined.

The remainder of the paper is structured as follows: section 2 introduces the Prototype Theory (PT), which serves as a theoretical framework for the discussion; section 3, with the help of PT, defines the prototypical form of the Slavic word; section 4 establishes the closing (by default) character of Slavic Movierung suffixes; section 5 addresses instances where Movierung suffixes are not closing and explains the existence of such exceptions; section 6 explores a typological explanation of the results obtained in the paper up to that point; and section 7 summarizes the main ideas of the paper and draws conclusions.

\section{Prototypes in Morphology}

In keeping with the fundamental principles of Cognitive grammar, I believe that linguistic categories are based on prototypes. For a definition of prototype I assume, with Langacker (1987), that "[a] prototype is a typical instance of a category, and other elements are assimilated to the category on the basis of their perceived resemblance to the prototype; there are degrees of membership based on degrees of similarity" (Langacker 1987: 371).

The notion of prototype informs my definition of the two main domains of morphology, namely derivation and inflection. In other words, I understand derivation and inflection as constituting a continuum situated between the poles of prototypical derivation and prototypical inflection (Dressler 1989). In one respect, derivation and inflection constitute a continuum and in another respect, they are distinct (cf. Anderson 1982; Perlmuter 1988; Beard 1995). This understanding is supported by analysis of the diachronic development of Slavic, wherein a tendency towards specialization of suffixes as either derivational or inflectional is established (cf. Manova 2005), as well as by the human mind's perception of reality. Thus, the fact that colours constitute a continuum (the so called colour spectrum) does not mean that we cannot distinguish between different colour shades. On the contrary, the mind tends to define in-between instances (imagine, for example, a shade between red $[\mathrm{X}]$ and orange $[\mathrm{Y}])$ as either $[\mathrm{X}]$ or $[\mathrm{Y}]$ and not as $[\mathrm{X}+\mathrm{Y}]$.

Perhaps the most significant distinction between prototypical derivation and prototypical inflection is in regard to word-class change. Prototypical derivation is word-class-changing, e.g. R. V rabot-at' 'to work' $\rightarrow \mathrm{N}$ rabot-nik 'work-er', whereas prototypical inflection is word-class-preserving, e.g. R. N NOM SG knig-a 'book' $\rightarrow \mathrm{N}$ GEN SG knig-y. Consequently, pairs such as Bg. N gradin-a 'garden' $\rightarrow \mathrm{N}$ gradin-ar 'garden-er', relating two different lexemes but without word-class change, represent non-prototypical derivation. As discussed in Manova (2005), I distinguish between non-prototypical derivation and non-prototypical inflection in an inflecting(-fusional) language according to the way in which a category relates to the in- 
flection class system of the respective language, i.e. non-prototypical inflection is always related either with a particular inflectional class or with phonologically complementary classes (thus identifiable inflectionally), whereas the output of non-prototypical derivation change is dispersed within a language's inflectional system and cannot be identified inflectionally (and therefore has derivational status). These definitions of non-prototypical derivation and inflection can be illustrated by the categories of noun diminutives and Movierung in Russian. Russian uses the following suf-

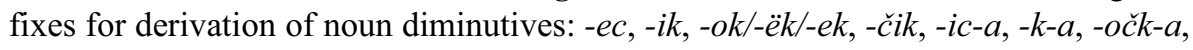
$-i k-o,-k-o,-c-o /-c-e,-e c-o$; and the following set of suffixes for formation of females from males: $-k-a,-i x-a,-i c-a,-n i c-a,-\check{s}-a,-n-a,-i n-j a,-u x-a,-e s s-a,-i s-a$. It is also well-known that depending on their phonological make-up Russian nouns inflect in accordance with four (major) inflection patterns (classes) - that of zakon 'law', komnata 'room', mesto 'place' and kost' 'bone' (cf. Corbett 1991: 36). In other words, a Russian noun diminutive can belong to one of three inflection classes, namely $z a$ kon, komnata or mesto, whereas Russian females derived from males inflect according to the komnata-type only (and therefore constitute [non-prototypical] inflection).

I further rely on the notion of prototype for the classification of morphological forms. When using a morphological word, one has some expectations about its (prototypical) structure: derivational suffixes follow the root, whereas inflectional suffixes are outside derivational suffixes, since thematic markers serve 'to predict' the set of inflection suffixes of a lexeme, thematic material is expected to precede the inflection, etc. On the basis of such expectations, I put forward a morphological construct that I call a prototypical form of the Slavic word and that is defined in the next section.

\section{THE PROTOTYPICAL FORM OF THE SLAVIC WORD}

Slavic languages are of the inflecting-fusional type and make a clear distinction between derivational and inflectional suffixes (cf. Skalička 1979). Based on this typological feature as well as on the universal principle of constructional iconicity (addition of semantics means addition of form) and the notion of prototype (as defined in the previous section), I assume for a Slavic word, a generalized structure involving the following slots (Manova 2005, 2006):

(2) (PREFIX)-BASE-(DERIVATIONAL SUFF)-(THEMATIC MARKER)-(INFLECTIONAL SUFF)

Clearly, prototypical derivation takes place in the derivational slot of the word, whereas prototypical inflection occupies the inflection word slot. TMs are recognized only in verbal morphology, where they have inflectional status (cf. the discussion in Manova 2006). The TM slot can be occupied by a single suffix only, which is not true of derivation and inflection suffix slots, which can host more than one suffix, e.g. Bg. uči-tel-sk-a-ta 'teacher's-FEM-DEF', with two derivational suffixes $(-t e l-s k$-) and two inflectional suffixes $(-a-t a)$. 
In some Slavic languages (e.g. Bulgarian), both non-prototypical derivation (e.g. noun diminutivization) and non-prototypical inflection (e.g. Movierung) use, in contrast to prototypical derivation and inflection, either the inflectional or the derivational slot of the word (Manova 2002, 2005). Consider the following examples of noun diminutivization:

(3) a. Bg. FEM knig- $\varnothing-a$ 'book' $\rightarrow$ DIM FEM kniž-k-a, DIM NEUT kniž-l-e

b. Bg. MASC măz- $\varnothing-\varnothing$ 'man' $\rightarrow$ DIM NEUT măz-l-e

c. Bg. MASC oven- $\varnothing-\varnothing$ 'ram' $\rightarrow$ DIM NEUT ovn- $\varnothing-e$

In such instances, $-k$ - and $-l$ - are seen as derivational whereas $-e$ is seen as an inflectional suffix. The same holds true in cases of non-prototypical inflection (Manova 2005), illustrated with the following examples of Movierung from Bulgarian:

(4a) učitel 'teacher' $\rightarrow$ FEM učitel-k-a

but

(4b) săprug 'husband' $\rightarrow$ FEM săprug- Ø- $a$ 'wife'

Note that non-prototypical inflection tends to prefer the derivational slot of the word, as seen in the following examples from Bulgarian, in which the suffix -kin(ja) replaces a suffix in the derivational word slot:

(5) bor-ec- Ø 'fighter' $\rightarrow$ FEM bor-kin-ja

sărb-in-Ø ‘(a) Serbian’ $\rightarrow$ FEM srăb-kin-ja

It should be mentioned that formation of females from males by addition of inflection only is entirely unproductive in Slavic (cf. Manova 2002).

In the oldest Slavic texts, in one and the same source, one finds parallel forms such as $r a b$ - $a$ and $r a b-y n-i$, both meaning 'slave-FEM, servant-FEM', and derived from the masculine noun $r a b b$ 'slave, servant' (cf. SJS). Therefore, it is difficult to establish which type of expression, that derived with a special gender suffix or that formed by addition of the inflection $-a$, is diachronically older. Note, however, that the suffix $-y n-i$ does not terminate in $-a$, as is usual for the rule of Movierung in some of the modern Slavic languages, i.e. in an older stage of the diachronic development of Slavic, Movierung formations were distributed between the phonologically complementary (hard vs. soft) $-a$ and $-j a$ stems, which means that Movierung slightly deviated from non-prototypical inflection towards non-prototypical derivation. This situation is still preserved in some of the Slavic languages. Consider:

(6) P. bóg 'God' $\rightarrow$ FEM bogini

Cz. bưh 'God' $\rightarrow$ FEM bohyne

Compare now the forms in (6) with Bg. bog 'God' $\rightarrow$ FEM boginja, R. bog 'God' $\rightarrow$ FEM boginja. Note that in Bulgarian and Russian, nouns terminating in - $a$ and -ja belong to the same inflectional class (cf. e.g. Corbett 1991: 36). In other words, Movierung is not precisely the same category in all Slavic languages, which results in slightly different behavior of Movierung suffixes when closing suffixation is concerned (cf. footnote 10). 


\section{Slavic MoVierung SUfFiXes ARE CLOSING (By DefaUlt)}

As mentioned in section 1, German Movierung suffix -in is closing, and more than $90 \%$ of all Movierung formations in German are derived through the attachment of this suffix. ${ }^{2}$ In other words, the fact that the suffix -in is closing is enough to determine German Movierung as closing in general. Although Slavic languages are richer in Movierung suffixes, Slavic Movierung suffixes seem to be closing as well (though see the next section). The closing character of two Slavic suffixes, the Bulgarian $-k-a$ and the Russian $-\check{s}-a$, is illustrated below, but this test can be applied to every Movierung suffix.

(7) Bg. profesor 'professor' $\rightarrow$ profesor- $k$ - $a$ 'female professor'

R. professor' 'professor' $\rightarrow$ professor- $-\check{s}-a$ 'female professor'

Consider now the following examples of adjectivization, verbalization and diminutivization, i.e. all possible productive derivational rules applicable to noun bases:

Adjectivization:

(8a) Bg. profesor $\rightarrow$ ADJ profesor-ski

R. professor $\rightarrow$ ADJ professor-skij

but

(8b) Bg. profesor- $k-a \rightarrow \mathrm{ADJ} \varnothing$

R. professor-šs- $a \rightarrow \mathrm{ADJ} \varnothing^{3}$

\section{Verbalization ${ }^{4}$ :}

(9a) Bg. profesor $\rightarrow \mathrm{V}$ profesor-stvam but R. professor $\rightarrow \mathrm{V}$ professor-stvovat'

(9b) Bg. profesor- $k-a \rightarrow \mathrm{V} \varnothing$

R. professor- $-\check{s}-a \rightarrow \mathrm{V} \varnothing$

\section{Diminutivization:}

(10a) Bg. profesor $\rightarrow$ DIM profesor-če but

$$
\mathrm{R} \text {. professor } \rightarrow \text { DIM professor-ok }
$$

${ }^{2}$ Except -in, modern German uses for Movierung also -(i/e)sse, -euse, -ine, -esse and -sche (dialectal, North German), formations with these suffixes, however, often have -in doublets or allow addition of -in, e.g. Baron-esse and Baron-in, as well as Prinz-ess-in (cf. Wellmann 1975: $107 \mathrm{ff}$ ).

${ }^{3}$ Note that according to the Russian Academy Grammar (1980: 270), professoršin 'female professor's' should be an existing form, parallel to direktoršin 'female director's' (a single occurrence in the RNC). Professoršin, however, could be found neither in the RNC nor in Google.

4 These verbalizations may be seen as derived from the respective -stvo nouns as well, i.e. from Bg. profesorstvo, R. professorstvo, both meaning 'being a professor'.

${ }^{5}$ In the RNC, there is only one single occurrence of a diminutive from professor профессорок. Google could find 25 pages in Russian where профессорок is used, as well as seven with профессорик (Search results from 12.07.07). 
(10b) Bg. profesor- $k-a \rightarrow$ DIM ø

R. professor- $\check{s}-a \rightarrow \mathrm{DIM} \varnothing$

It should be mentioned here that there is a typological distinction between English (without productive Movierung) and German/Bulgarian/Russian, and English Movierung suffixes are not closing (examples from Hay - Plag 2004):

$\begin{aligned} \text { E. prince } \rightarrow \quad \text { princess } \rightarrow \quad & \begin{array}{l}\text { princessdom } \\ \text { princessship } \\ \text { princesshood } \\ \text { princessly } \\ \text { princessless }\end{array}\end{aligned}$

Note that the closing character of the Slavic Movierung suffixes is not due to coincidences with other suffixes, but to Movierung itself, i.e. if a Movierung suffix has a homophonous derivational suffix, the latter is not closing, as can be seen in the following examples:

(12) Bg. profesor 'professor' $\rightarrow$ profesor- $k$ - $a$ 'female professor'

Bg. snim-am 'to take a picture' $\rightarrow$ snim- $k-a$ 'a photograph'

R. prepodavatel' 'professor' $\rightarrow$ prepodavatel'-nic-a 'female professor'

R. mel-it' 'to mill' $\rightarrow$ mel'-nic- $a$ 'a mill'

Adjectivization:

(13) Bg. snim- $k-a \rightarrow$ ADJ snimk-ov

Bg. profesor- $k-a \rightarrow$ ADJ ø

Bg. mel'-nic- $a \rightarrow$ ADJ mel'nič-nyj

R. prepodavatel'-nic- $a \rightarrow \mathrm{ADJ} \varnothing$

Diminutivization:

(14) Bg. snim- $k$ - $a \rightarrow$ DIM snim- $\check{c}-i c-a$

Bg. profesor- $k-a \rightarrow \mathrm{DIM} \varnothing$

R. mel'-nic- $a \rightarrow$ DIM mel'nič- $k$ - $a$

$\mathrm{R}$. prepodavatel'-nic- $a \rightarrow \mathrm{DIM} \varnothing$

In sum, Bulgarian and Russian Movierung suffixes are, like the German Movierung suffix -in, closing (generally speaking, see the next section). Tests with homophonous derivational suffixes show that the closing character of the Bulgarian and Russian suffixes used for derivation of females from males is due to the semantic meaning Movierung.

\section{EXCEPTIONS AND WHAT THEY REVEAL ABOUT THE NATURE OF CLOSING SUFFIXATION}

Slavic Movierung suffixes are not exclusively closing and exhibit a number of exceptions ${ }^{6}$. It should be noted that failure to account adequately for exceptions is the most severe criticism levied against Aronoff \& Fuhrhop 2002 who have offered

${ }^{6}$ Note that some of the German Movierung suffixes are not closing either, e.g. Prinz-esschen (cf. Wellmann 1975: 111). 
the only systematic explanation of closing suffixation (and negative restrictions on affix order in general) in morphological theory thus far. Unfortunately, the problem with exceptions, though undoubtedly of particular importance to the theoretical potential of the idea of closing suffixation, has been left opened - by Aronoff \& Fuhrhop as well as by their opponents. Therefore in this section, we focus on exceptions from the closing character of Movierung in order to establish whether they occur by chance (i.e. are unclassifiable and thus undermine the idea of systematically occuring closing suffixation) or systematically in a way that is telling regarding the nature of the closing suffixation. The discussion is supported by diminutivization data from Bulgarian, since in this language diminutivization is extremely productive, much more productive than adjectivization and verbalization (and more productive than in Russian, as we could see above), which thus increases the likelihood of finding exceptions.

Besides the inflection - $a$, Bulgarian possesses the following Movierung suffixes:

$$
\begin{aligned}
& \text {-k-a (e.g. učitelka } \leftarrow \text { učitel 'teacher') } \\
& \text {-in-ja (e.g. boginja } \leftarrow \text { bog 'God') } \\
& \text {-kin-ja (e.g. srăbkinja } \leftarrow \text { sărbin 'a Serbe') } \\
& \text {-ic-a (e.g. magarica } \leftarrow \text { magare 'donkey') } \\
& \text {-es-a (e.g. poetesa } \leftarrow \text { poet 'poet') } \\
& \text {-is-a (e.g. aktrisa } \leftarrow \text { akt'or 'actor') and } \\
& \text {-v-a (only in svekărva } \leftarrow \text { svekăr 'father-in-law') }
\end{aligned}
$$

Diminutivization in Bulgarian uses -ec; $-k-a$; $-i c-a$; -čic- $a$; -ičk-a; -c-e; -enc-e; $-i c-e ;-l-e ;-\check{c}-e$. Of the latter suffixes, due to phonological selectional restrictions, only $-k-a$; $-i c-a$; $-\check{c} i c-a$; $-i c ̌ k-a$, and occasionally $-\check{c}-e$ and -enc-e are relevant to the discussion.

According to the prototypical structure of the Slavic word, the exceptions to the closing character of Movierung can be distributed into three main groups with the following subgroups:

A) Females derived from males without a suffix in the derivational word slot:

A1) săprug 'husband' $\rightarrow$ FEM săprug- $\varnothing-a$ 'wife' $\rightarrow$ DIM săpruž- $k-a$ (Google ${ }^{7}-1$ occurrence);

A2) Xik $\rightarrow$ Xic- $a$, e.g. čistnik 'fastidious person' $\rightarrow$ FEM čistnic- $a \rightarrow$ DIM čistnič- $k-a$; xubostnik 'scamp' $\rightarrow$ FEM xubostnic- $a \rightarrow$ DIM xubostnič- $k-a$ (note that čistnička and xubostnička are labeled by some as neutral formations, i.e. as neutral as čistnica and xubostnica rather than diminutives).

Here one should also consider the in-between instances kum 'first witness' $\rightarrow$ FEM kum- $\varnothing-a$ (! but also kum-ic- $a) \rightarrow$ DIM kum-ickk- $a$ (Google - 147 occurrences) and krăstnik 'godfather' $\rightarrow$ FEM krăstnic- $a \rightarrow$ DIM krăstnič-ka (Google - 18 oc-

\footnotetext{
${ }^{7}$ Since diminutives are extremely productive, they are not (or are only seldom) listed in dictionaries, therefore I decided to use as evidence Google. All Google results cited in this section are from 19.08.2007.
} 
curences). I classify these examples as in-between because kumička and krăstnička can also be seen as denoting children, cf. the discussion in $\mathrm{C} 3$ below.

B) Females that are basic nouns (i.e. not derived from males):

B1) Suppletion

petel 'cock' - kokoš- $k$ - $a$ 'hen' $\rightarrow$ DIM kokošč-ic-a (cf. the adjective kokoš- $i$ 'hen-')

Also belonging to this subtype are examples such as badžanak 'brother-in-law' etărv- $a$ 'sister-in-law' $\rightarrow$ DIM etărv-ičk- $a$ and dever 'brother-in-law' - zălv- $a$ 'sister-in-law' $\rightarrow$ DIM zălv-ičk-a. Consider also bašta 'father' - majk-a 'mother' $\rightarrow \mathrm{N}$ majč-ic-a (endearment) and the ADJ majč-in 'mother's'.

B2) Female animals that are basic nouns, i.e. the males are derived from the females (semantically) and not vice versa, as is the case in Movierung:

găs-k-a 'goose' $\rightarrow$ DIM găsč-ic-a (cf. găs-k-a $\rightarrow$ MASC găs-ok where găska is the semantically unmarked member)

$m i \check{s}-k$ - $a$ 'mouse' $\rightarrow$ DIM mišč-ic- $a$ (cf. miš- $k$ - $a \rightarrow$ MASC miš-ok)

$k a ̆ r t i c-a$ 'mole' $\rightarrow$ DIM kărtič- $k$-a (cf. MASC kărt; note that kărtica is the semantically basic noun, i.e. it can remain for kărt but not vice versa)

lis- $a$ \& lis-ic- $a$ 'fox' $\rightarrow$ DIM lis-ič- $k$ - $a$ (but consider also lis- $a$ 'fox' $\rightarrow$ MASC lis$a n$, and the forms FEM lis-an- $a$ and MASC lis-ik)

Clearly, nouns for animals and birds such as ptica 'bird', mravka 'ant', văška 'louse', etc. that terminate in phonological segments homophonous with Movierung suffixes but which do not express Movierung, can be diminutivized freely. Consider: ptička, ptičica, mravčica, văščica, etc.

C) Females derived from males by addition of Movierung suffixes in the derivational word slot:

C1) Female animals:

magare 'donkey' $\rightarrow$ FEM magar-ic- $a \rightarrow$ DIM magarič- $k$ - $a$ (Google - 683 occurrences)

lăv 'lion' $\rightarrow$ FEM lăv-ic- $a \rightarrow$ DIM lăvič- $k$ - $a$ (Google -8 occurences)

The only instance of a derivation involving a human being is svekăr 'father-in-law' $\rightarrow$ svekăr-v-a 'mother-in-law' $\rightarrow$ svekărv-ičk- $a$ (rather ironical) (Google - 82 occurrences), svekărva being derived with the unique Movierung suffix - $v-a$ (note that nouns such as etărva 'sister-in-law', zălva 'sister-in-law', though terminating in -v-a are non-derived, cf. B1 above);

C2) Females derived with foreign Movierung suffixes:

princ 'prince' $\rightarrow$ FEM princ-es- $a \rightarrow$ DIM princes- $k$ - $a$ (Google -528 occurrences)

poet 'poet' $\rightarrow$ FEM poet-es- $a \rightarrow$ DIM poetes- $k$ - $a$ (Google -236 occurrences)

baron 'baron' $\rightarrow$ FEM baron-es- $a \rightarrow$ DIM barones- $k$ - $a$ (Google -1 occurrence)

$a k t$ 'or 'actor' $\rightarrow$ FEM aktr-is- $a \rightarrow$ DIM aktris- $k$ - $a$ (Google -54 occurrences)

C3) Nouns for children derived from ethnics:

rus-nak 'a Russian' $\rightarrow$ FEM rus-kin-ja - rus-kin-č-e

turč-in 'a Turk' $\rightarrow$ FEM turk-in-ja-turk-in-č-e

sărb-in 'a Serb' $\rightarrow$ FEM srăb-kin-ja - srăb-kin-č-e

Actually, these examples are not problematic for systematic closing suffixation since the semantics of 'child' can be motivated neither from the noun for a female 
person nor from the noun for a male person but should be seen as derived from a mutual base by the addition of -kinče.

C4) Lexicalizations

daskal 'teacher (archaic)' $\rightarrow$ FEM daskal-ic- $a \rightarrow$ DIM daskalič-k-a 'little female teacher \& little female pupil'

princ-es-a '1. princess; 2. warm sandwich' $\rightarrow$ DIM princes- $k$ - $a$

Note that some native speakers see the derivation učitel 'teacher' $\rightarrow$ učitelka $\rightarrow$ ?/* DIM učitelčica (related to daskal $\rightarrow$ daskalica in C4, as well as to the examples in C1) as possible. Google, however, could find no single use of učitelčica.

In sum, exceptions to the closing character of Movierung seem numerous at first sight, but they occur systematically and are explained easily. Actually, none of the exceptions cited above undermines the idea of systematic closing suffixation but only demonstrates: a) that the mechanism of closing suffixation is more complex than just distributing the suffixes of a particular language into two groups - 'closing' and 'non-closing'; and b) that factors such as semantics (cf. C1, C3 and C4) and morphological structure (cf. A, B, and C2) of the base are of particular importance for the proper functioning of closing suffixation analysis.

Termination in the same segment (phonological coincidence whether due to diachronic reasons or not) is irrelevant to closing suffixation if the phonologically coinciding segments do not represent a suffixed morphotactic unit (i.e. a suffixed morpheme).

\section{TOWARDS A TYPOLOGICAL EXPLANATION OF THE RESULTS OBTAINED}

Slavic languages represent the inflecting-fusional type that makes a clear distinction between derivational and inflectional suffixes and for which gender is a typespecific category (Dressler 1985). Further, the strongly inflecting Slavic languages (in contrast to the less inflecting German) allow for derivational and inflectional realizations of non-prototypical inflection such as gender in terms of Movierung. Thus, females derived from males are either of the type [X + GENDER SUFF + INFL SUFF] or of the type [X+ø+INFL SUFF], the former being the default expression of Movierung in Slavic. Movierung is, however, not exactly the same category in all Slavic languages - in some languages (e.g. Bulgarian and Russian), Movierung formations are related to a particular inflectional class, whereas in other Slavic languages (e.g. Czech and Polish), Movierung formations enter two phonologically complementary inflectional classes (they are thus less clear instances of non-prototypical inflection than Movierung formations in Bulgarian and Russian) and allow either productive attachment of the possessive adjective suffix $-i n^{8}$ or

${ }^{8}$ It should be noted here that the possessive adjective suffix -in is specialized for the expression of single (definite) possession primarily with nouns denoting female humans, but actually, -in appears synonymous (and even equivalent) to the genitive case inflection. Thus, for example in Polish, the norm allows replacement of -in adjectives by genitive 
diminutivization ${ }^{9}$ ). Of the two types of realization of Movierung in Slavic, however, only that using the derivational suffix slot of the word is closing ${ }^{10}$ (in the sense that nouns derived in this way cannot serve as bases for adjectivization, verbalization and diminutivization). This result is a logical one - if material from the derivational suffix slot closes the word for the addition of further suffixation, an empty derivational slot cannot have such properties. Intriguingly, if in the derivational suffix slot there is a suffix homophonous with a Movierung suffix, the former is not closing, which thus gives rise to questions about the morphological status of Movierung suffixes. The non-closing character of prototypically derivational suffixes may be seen as further evidence for the non-derivational (i.e. inflectional) character of $\mathrm{Mo}$ vierung suffixes (recall the discussion in sections 2 and 3 above). Moreover, it can be established that there are only a few nouns for female animals (derived with the addition of a suffix in the derivational slot) that allow diminutivization (plus a few lexicalizations and a few nouns derived with foreign Movierung suffixes). However, Movierung with 'animals' bases differ from Movierung with 'persons' bases as animals exhibit both MASC $\rightarrow$ FEM and FEM $\rightarrow$ MASC direction of derivation, i.e. Movierung with animals is much more derivational than Movierung with persons, which is always only MASC $\rightarrow$ FEM. Thus, the exceptions established in the previous section further support the correctness of the claim about (nonprototypical) inflectional character of Movierung, i.e. it is the inflectional status of Movierung that blocks the addition of derivational suffixes. Further, if a language does not relate Movierung to a single inflection class due to typological reasons (as is the case of English), in such a language, Movierung is not closing. If the rule of Movierung is related to two phonologically complementary inflection classes, as is the case in some Slavic languages, Movierung allows (productive) addition of the possessive adjective suffix -in and, according to some native speakers, diminutivization $^{11}$, and it thus seems that the closing character of Movierung suffixes might be doubted (though cf. footnote 8).

case nouns (i.e. matczyna chustka 'mother's scarf' = chustka matki), whereas in Czech the prescriptive norm requires possessive adjectives, the latter, however, compete with the genitive case forms in informal discourse.

9 Diminutives from females derived from males are, by rule, not listed in dictionaries but are evaluated as acceptable by some speakers (primarily native speakers of Polish) and can be found in Gooogle.

10 Clearly, no derivational suffix can be added after the inflection $-a$, but this restriction differs from the type of restrictions we discuss herein.

11 Problematic for this conclusion appear languages such as Serbian and Croatian where Movierung is related to a single inflection class but from derived females, one can form possessive adjectives productively, although it should be stressed that Google tends to evidence that possessive adjectives are much frequent in Croatian than in Serbian. 


\section{Conclusion}

Movierung (primarily in Bulgarian and Russian) has been analyzed in regard to closing suffixation and the (prototypical) structure of the Slavic word. Slavic Movierung is a clear case of a non-prototypical category, in the sense that Movierung changes allow for derivational and inflectional realizations. Movierung, however, is not exactly the same in all Slavic languages, i.e. in some languages, it is a clear case of non-prototypical inflection, whereas in other languages, it, since related to two (though phonologically complementary) inflection classes, deviates from nonprototypical inflection towards non-prototypical derivation. Moreover, Movierung with persons differs from Movierung with animals (the latter tends to nonprototypical derivation, whereas the former to non-prototypical inflection). Of the two types of expression of Movierung only that with a suffix in the derivational slot (i.e. parallel to the German -in formations) is closing in the languages discussed in the sense that after Movierung suffixes adjectivization, verbalization and diminutivization (the most productive derivational rules with noun bases) are either impossible or restricted in a specific way (e.g. the possessive adjective suffix -in can attach after Movierung suffixes). An exact analysis of the exceptions of closing character of Movierung found in Bulgarian has shown that they are semantically and morphotactically definable. Closing semantics is defined via its morphotactics (only females derived from human males with a suffix in the derivational word slot cannot serve as bases for further derivations), and closing morphotactics is defined via its semantics (in case of homophonous suffixes and final segments, semantics determines the $+/$ closing character of a suffix/segment). $+/$ - foreign is also a relevant criterion for the establishing of a closing suffix - foreign Movierung suffixes are not closing. The closing character of overt Movierung suffixes is explained easily if seen as a result of the inflectional character of Movierung.

\section{$\mathrm{References}$}

Anderson 1982: $\quad$ Stephen R. Anderson, Where's Morphology? Linguistic Inquiry 13, 571-612

Aronoff - Fuhrhop 2002: Mark Aronoff, Nanna Fuhrhop, Restricting Suffix Combinations in German and English: Closing Suffixes and the Monosuffix Constraint, Natural Language and Linguistic Theory 20, 451-490

Baker 1985: Mark Baker, The Mirror Principle and Morphosyntactic Explanation, Linguistic Inquiry 16, 373-415

Beard 1995:

Bybee 1985:

Robert Beard, Lexeme-Morpheme Base Morphology, Albany

Corbett 1991: Joan L. Bybee, Morphology. A Study of the Relation between Meaning and Form, Amsterdam

Dressler 1985: Greville G. Corbett, Gender, Cambridge Wolfgang U. Dressler, Typological Aspects of Natural Morphology, Wiener Linguistische Gazette 36, 3-26 [Acta Linguistica Hungarica 35, 1987, 51-70] 
Dressler 1989:

Fabb 1988:

Giegerich 1999:

Greenberg 1963: Grimshaw 1986:

Hay 2003:

Hay - Plag 2004:

Kiparsky 1982:

Langacker 1987:

Manova 2002:

Manova 2005:

Manova 2006:

Mohanan 1986:

Nida 1949:

Plag 1996:

Perlmutter 1988:

Rice 2000:

Russian Academy Gran

I. Fonetika, Fonologija, Udarenie, Intonacija, Slovoobrazovanie, Morfologija, Moskva

Russian National Corpus: Russian National Corpus = Национальный корпус русского языка, http://www.ruscorpora.ru/

SJS 1982:

Skalička 1979:

Siegel 1974:

Spencer 2006:

Wolfgang U. Dressler, Prototypical differences between inflection and derivation, Zeitschrift für Phonetik, Sprachwissenschaft und Kommunikationsforschung 42, 3-10

Nigel Fabb, English suffixation is constrained only by selectional restrictions, Natural Language and Linguistic Theory 6, 527-539

Heinz J. Giegerich, Lexical Strata in English. Morphological Causes, Phonological Effects, Cambridge

Joseph H. Greenberg (ed.), Universals of language, Cambridge

Jane Grimshaw, A Morphosyntactic Explanation for the Mirror Principle, Linguistic Inquiry 17, 745-749

Jennifer Hay, Causes and Consequences of Word Structure, New York and London

Jennifer Hay, Ingo Plag, What constrains possible suffix combinations? On the interaction of grammatical and processing restrictions in derivational morphology, Natural Language and Linguistic Theory 22, 565-596

Paul Kiparsky, Lexical morphology and phonology, in: Linguistics in the Morning Calm: Selected Papers from SICOL - 1981, Linguistic Society of Korea, Seoul, 3-91

Ronald W. Langacker, Foundations of cognitive grammar. Vol. I. Theoretical Prerequisites, Stanford

Stela Manova, Between derivation and inflection: on morphotactic expression of aspect and gender in Bulgarian, Russian and SerboCroatian, Wiener Slavistisches Jahrbuch 48, 203-217

Stela Manova, Derivation versus Inflection in three Inflecting Languages, in: Wolfgang U. Dressler, Dieter Kastovsky, Oskar Pfeiffer, Franz Rainer, Morphology and its Demarcations. Selected papers from the $11^{\text {th }}$ International Morphology Meeting, Vienna February 2004, Amsterdam - Philadelphia, 233-252

Stela Manova, A theory of morphological clines: With special emphasis on conversion and subtraction in Bulgarian, Russian and SerboCroatian. (under review), $280+\mathrm{xx} \mathrm{pp}$. [This is a revised version of Manova 2003. Conversion and Subtraction in Bulgarian, Russian and Serbo-Croatian. Ph.D. Thesis University of Vienna.]

Karuvannur P. Mohanan, The Theory of Lexical Phonology, Dordrecht

Eugene A. Nida, Morphology: The Descriptive Analysis of Words, $2^{\text {nd }}$ ed., Ann Arbor

Ingo Plag, Selectional restrictions in English suffixation revisited. A reply to Fabb (1988), Linguistics 34, 769-798

David Perlmutter, The Split Morphology Hypothesis: Evidence from Yiddish, in M. Hammond, M. Noonan (eds.), Theoretical Morphology, San Diego, CA, 79-100

Keren Rice, Morpheme Order and Semantic Scope, Cambridge

SJS = Slovník jazyka staroslověnského. Lexicon Linguae Palaeoslovenicae Vol. 3, Praha

Vladimir Skalička, Typologische Studien, Ed. by P. Hartmann, Wiesbaden

Dorothy Siegel, Topics in English Morphology, Ph.D. Thesis, MIT

Andrew Spencer, Morphological universals, in: R. Mairal and J. Gil (eds.), Linguistic Universals, Cambridge, 101-129 
Szymanek 2000: $\quad$ Bogdan Szymanek, On morphotactics: Closing morphemes in English, in: B. Rozwadowska (ed.), PASE Papers in Language Studies, Wrocław, 311-320

Wellmann 1975: Hans Wellmann, Deutsche Wortbildung 2 - Das Substantiv, Düsseldorf

Acknowledgements: I am grateful to Lanko Marušič, Stefan M. Newerkla, Bogdan Szymanek and Tat'ána Vykypělová for useful comments and suggestions. All errors are my own.

\section{Stela Manova}

Institut für Slawistik der Universität Wien

Universitätscampus AAKH, Hof 3

Spitalgasse 2, 1090 Wien, Österreich

stela.manova@univie.ac.at 